\title{
Correlation of Vitamin D Serum Levels with Muscle Mass, Muscle Strength, and Physical Performance in the Elderly Community in Mohammad Hoesin General Hospital Palembang
}

\author{
Noveldy Calzoum Bachry ${ }^{*}$, Nur Riviati ${ }^{1}$, Yulianto kusnadi ${ }^{1}$, Erial Bahar ${ }^{2}$
}

${ }^{1}$ Department of Internal Medicine, Faculty of Medicine, Universitas Sriwijaya. Palembang, Indonesia

${ }^{2}$ Department of Anatomy, Faculty of Medicine, Universitas Sriwijaya, Palembang, Indonesia

\section{A R T I C L E I N F O \\ Keywords: \\ Advanced age \\ Vitamin D \\ Muscle mass \\ Muscle strength \\ Physical performance \\ RSMH Palembang \\ *Corresponding author: \\ Noveldy Calzoum Bachry \\ E-mail address: noveldy@gmail.com}

All authors have reviewed and approved the final version of the manuscript.

https://doi.org/10.32539/bsm.v5i3.226

\begin{abstract}
A B S T R A C T
Background: Older people tend to have decreased activity and intake of macronutrients and micronutrients that are not in accordance with the body's needs. Research in 2017 on elderly men and women at the Center for Family Compensation (PUSAKA) in Central Jakarta showed that $80.2 \%$ of elderly people have vitamin D deficiency. Low serum levels of vitamin D in the body are the initial risk of decreased muscle mass and physical performance in old age. where there is a significant correlation between low serum vitamin D levels in the body with sarcopenia and mortality. The purpose of this study was to determine the correlation of vitamin D levels with muscle mass, muscle strength and physical performance in the elderly community at RSMH Palembang. Methods: This research is a study analytic observation with a cross-sectional approach that was carried out at the Integrated Geriatric Clinic Internal Medicine RSMH Palembang from November 2019 to November 2020. A sample of 34 people aged $>60$ years were examined for muscle mass, muscle strength, physical performance and serum vitamin D levels. All processing and analysis The data in this study used SPSS version 25 for Windows. Results: From 34 subjects, it was found that there were 29 women $(85.3 \%)$ and 5 men $(14.7 \%)$. The mean value of muscle mass is $38.76 \pm 4.1 \mathrm{~kg} / \mathrm{m} 2$, long runs within 6 meters $6.12 \pm 0.9 \mathrm{~m} / \mathrm{sec}$, and hand grip strength $24.9 \pm 5.2 \mathrm{~kg}$. It was found that $18(62.1 \%)$ female samples had vitamin D deficiency while $11(37.9 \%)$ samples had vitamin D insufficiency. There was a significant correlation between muscle mass and hand grip strength with vitamin $\mathrm{D}$ with weak correlation strength and length of walking with vitamin D with moderate correlation strength. Conclusion: There is a significant correlation between muscle mass and grip strength and walking time of 6 meters with vitamin D.
\end{abstract}

\section{Introduction}

As they age, their lifestyle and dietary diet change, older people tend to have decreased activity and intake of macronutrients and micronutrients that are not in accordance with the body's needs. Boy in 2019 found that $59.2 \%$ of 100 elderly people in Medan are at risk of malnutrition, and $3.2 \%$ of elderly people experience malnutrition. ${ }^{1}$ advancing to aging conditions such as frailty, lack of muscle mass, and lack of muscle strength. ${ }^{2}$ Therefore people aged $\geq 60$ years often have a health problem called geriatric syndrome. In general, geriatric syndrome is a condition in which muscle mass and function gradually decrease. ${ }^{2}$

Setiati et al in 2014, reported the number of patients with low hand grip strength of $8 \%$ and limited mobility of $2.8 \%$ of 251 outpatient geriatric patients. ${ }^{3}$ A 2017 study of elderly men and women in the Family Compensation Center ( PUSAKA) Central Jakarta shows that $80.2 \%$ of elderly people have vitamin D 
deficiency. ${ }^{4}$ Caniago et al. In 2019 found $4.3 \%$ of elderly people with vitamin D deficiency and $19.1 \%$ of elderly people who experience vitamin $\mathrm{D}$ insufficiency have weak hand grip strength. ${ }^{5}$ Yazar et al. In 2019 concluded, the increasing age, the lower the serum vitamin D levels in the body. ${ }^{1}$ Some clinical problems that often occur in geriatric syndrome are weak muscles, easy falls and the body becomes weaker (frailty). 6 Osteopenia / osteoporosis and sarcopenia are examples of problems that may occur in elderly people (elderly). ${ }^{6}$

When carrying out its role, vitamin $\mathrm{D}$ is bound to vitamin $\mathrm{D}$ receptors (VDR) which play a role in the immune system, so that vitamin D deficiency can increase the inflammatory process, in old age this inflammation is also called inflammation due to aging. ${ }^{7,8}$ In addition to bone mineralization and plays a role in preserving bone integrity and controlling the production and secretion of parathyroid hormone (PTH). ${ }^{9}$ When the body is deficient in vitamin D levels, VDR-RXR automatically takes protein bonds through muscle mass and calcium through bone mass. This can have an impact on decreased muscle function, physical performance and an increased risk of sarcopenia. ${ }^{8}$

According to EWGSOP 2 (2018) sarcopenia is a condition of skeletal muscle dysfunction characterized by decreased muscle strength, reduced muscle mass (quantitative and qualitative) and decreased physical ability. ${ }^{9}$ Sarcopenia can be differentiated based on its cause in primary sarcopenia, usually in the elderly and secondary sarcopenia namely decreased muscle function due to other causes such as chronic disease, lying down for a long time, low physical activity, being in an area with low gravity, metabolic disorders and poor nutritional intake. ${ }^{10}$

Conzade et al in 2019 concluded that low serum vitamin $\mathrm{D}$ levels in the body are an initial risk of decreased muscle mass and physical performance in old age, there is a significant correlation between low serum vitamin D levels in the body with sarcopenia and death. ${ }^{10}$ At the cellular level, serum levels vitamin D has an impact on muscle function which is divided into: 1 .
Genomic effects, which increase the 1.25D-VDR-RXR binding as a receptor to increase gene expression; 2 . Non-genomic effects which increase the signal transduction pathway in intra-cellular after binding to $1.25 \mathrm{D}$ which can regulate protein kinase in muscle skeleton. ${ }^{11,12}$

Liberman et al in 2019 concluded that elderly people who have vitamin D deficiency have high levels of IL6, IL8 and CRP so they suffer from sarcopenia and chronic low-grade inflammatory profile (CLIP), after consuming $800 \mathrm{IU}$ of vitamin D and $1200 \mathrm{mg}$ of calcium in 13 weeks, there is an inverse correlation where the increase in serum vitamin $\mathrm{D}$ levels in the body can reduce IL6 and IL8 levels and improve CLIP and physical performance. ${ }^{11}$

In line with Liberman et al, Garcia et al.2019 in a review study concluded that vitamin $\mathrm{D}$ is associated with muscle fiber metabolism expressed by VDR, serum vitamin D levels are directly related to age, sex and pathological factors in influencing decreased muscle mass and muscle function. and muscle strength in the elderly. ${ }^{13} \mathrm{El} \mathrm{Hajj}$ et al. 2019 found that giving Cholacalciferol $10.000 \mathrm{IU}$ for 6 months was proven to increase muscle mass and physical performance in those with pre-sarcopenia and sarcopenia. ${ }^{14}$

Different from the study Ceglia et al. found that a cross sectional study did not find a consistent relationship between vitamin D and muscle mass. It is explained that in healthy elderly people there is a decrease in muscle strength and accompanied by severe comorbidity of disease combined with low levels of physical activity can cause muscle weakness and daily functional disorders that cannot be prevented by giving vitamin D supplementation.

There is very little understanding of the importance of vitamin $\mathrm{D}$ in the general public, coupled with inadequate nutritional intake and decreased physical activity and other risk factors, putting the elderly at risk of frailty, decreased muscle mass, decreased muscle strength, osteoporosis and sarcopenia. Because the research on sarcopenia in Indonesia is 
characterized by a decrease in muscle mass, muscle strength and physical performance of the elderly in healthy elderly communities, this study aims to determine the correlation of serum vitamin D levels with muscle mass, hand grip and walking speed in the elderly. at RSMH Palembang. This study is expected to be a preliminary study on the importance of knowing serum vitamin D levels in the elderly in order to improve the quality of life of the elderly, prevent and treat sarcopenia.

\section{Methods}

This research is an observational analytic study with cross sectional design. The target population in this study were all elderly patients in the elderly community at RSMH Palembang. The affordable population is all samples aged $\geq 60$ years who are members of the elderly community at RSMH Palembang. The research subjects were 34 people who met the inclusion and exclusion criteria. Inclusion criteria were elderly aged $\geq 60$ years, able to communicate well and understandably, willing to participate in research and sign informed consent. The exclusion criteria were subjects with acute conditions or illnesses, subjects with autoimmune diseases, subjects with severe liver or kidney disorders, subjects with malignant diseases.

The independent variables are muscle mass, muscle strength, and physical performance. The dependent variable: serum Vitamin D levels. Confounding variables: age, gender, physical activity, smoking. The selection of research subjects was carried out by using the concecutive sampling technique, in which patients who met the inclusion criteria were taken as samples until they met the specified number. Patients were drawn from the elderly community or geriatric patients at RSMH Palembang. Processing and data analysis using the SPSS 25 for Windows program. Data is presented in tables and graphs. Univariate, bivariate analysis and correlation test between variables were performed.

\section{Results}

Table 1 shows the baseline characteristics of the study subjects, where the majority of study subjects were women, aged between 60-70 years.

This study obtained samples with an average vitamin D level of $18.4 \pm 6.29 \mathrm{ng} / \mathrm{mL}$. Serum vitamin D levels in this study were dominated by 21 (61.8\%) samples with vitamin D deficiency (vitamin D serum levels $<20 \mathrm{ng} / \mathrm{mL})$ and $13 \quad(38.2 \%)$ samples experiencing insufficiency (vitamin D levels. 20-30 $\mathrm{ng} / \mathrm{mL})$.

Table 2. displays data regarding serum vitamin $\mathrm{D}$ levels in the elderly. In this study, 18 (62.1\%) samples of women had vitamin D deficiency while 11 (37.9\%) samples had vitamin D insufficiency, obtained 3 (60\%) samples of men who experienced vitamin D deficiency while $2(40 \%)$ ) others experienced vitamin D insufficiency. At age, 18 (62.1\%) samples aged $\leq 70$ years experienced vitamin D deficiency while 11 $(37.9 \%)$ samples had vitamin D insufficiency, obtained $3(60 \%)$ samples > 70 years experienced vitamin D deficiency while the other $2(40 \%)$ had vitamin D insufficiency.

Samples with vitamin D insufficiency had a mean muscle mass of $38.76 \pm 4.1 \mathrm{~kg} / \mathrm{m}^{2}$, an average walking speed of $6.12 \pm 0.9 \mathrm{~m} / \mathrm{s}$ and a hand grip strength of $24.9 \pm 5.2$. kg. samples with vitamin D deficiency had a mean muscle mass of $38.68 \pm 6.09 \mathrm{~kg} / \mathrm{m}^{2}$, an average walking speed in $6 \mathrm{~m}$ of $6.77 \pm 1.67 \mathrm{~m} / \mathrm{sec}$ and a hand grip strength of $24.9 \pm 5.2 \mathrm{~kg}$. The results of the analysis using the chi square and one way Anova showed that there was no significant relationship between gender, age, muscle mass, walking speed and hand grip strength.

The results of this study using the Pearson test showed that there was a significant correlation between muscle mass and grip strength with vitamin D with weak correlation strength and walking speed with vitamin $\mathrm{D}$ with moderate correlation strength. Can be seen in Table 3 and Figure 1.

The results of multivariate analysis using linear regression with the dependent variable of vitamin $D$ 
showed that the correlation with vitamin $\mathrm{D}$ in this study was age with very weak negative correlation strength (-0.192) and muscle mass with moderate correlation strength. Based on table 4.4. interpreted, the increasing age, the lower the vitamin D levels in the body and the lower the vitamin D levels, the smaller the muscle mass.

Table 1. Baseline Characteristics

\begin{tabular}{rll}
\hline Sample Characteristics & N (\%) \\
\hline Sex & & \\
$\bullet$ & Male & $5(14.7 \%)$ \\
- & Female & $29(85.3 \%)$ \\
Age & & $65 \pm 4.5$ years \\
• & 60-70 years & $29(85.3 \%)$ \\
Comorbid & $5(14.7 \%)$ \\
- Diabetes mellitus & \\
- Hypertension & $3(8.82 \%)$ \\
- Corona Artery Disease & $9(26.4 \%)$ \\
BMI & $3(8.82 \%)$ \\
• Less & $5(14.7 \%)$ \\
- Normal & $12(35.2 \%)$ \\
- Obesity & $6(17.6 \%)$ \\
\hline
\end{tabular}

Table 2. Serum Vitamin D Levels in the Elderly

\begin{tabular}{cccc}
\hline & Insufficiency & Deficiency & p \\
\hline Sex & & & \\
$\bullet \quad$ Male & $2(40 \%)$ & $3(60 \%)$ & $0.930^{\mathrm{a}}$ \\
Age (yo) & $11(37.9 \%)$ & $18(62.1 \%)$ & \\
$\bullet \quad \geq 60-70$ & & & \\
$\bullet \quad>70$ & $11(37.9 \%)$ & $18(62.1 \%)$ & $0.930^{\mathrm{a}}$ \\
Muscle mass & $2(40 \%)$ & $3(60 \%)$ & \\
Walking speed & $38.76 \pm 4.1 \mathrm{~kg} / \mathrm{m}^{2}$ & $38.68 \pm 6.09 \mathrm{~kg} / \mathrm{m}^{2}$ & $0.064^{\mathrm{b}}$ \\
Hand Grip Strength & $6.12 \pm 0.9 \mathrm{~m} / \mathrm{s}$ & $6.77 \pm 1.67 \mathrm{~m} / \mathrm{s}$ & $0.062^{\mathrm{b}}$ \\
\hline
\end{tabular}

Table 3. Correlation of Vitamin D levels with muscle mass, walking speed and hand grip

\begin{tabular}{lccc}
\hline & $\mathrm{r}$ & $\mathrm{p}$ & $\mathrm{N}$ \\
\hline Muscle mass & 0.178 & 0.044 & 34 \\
Walking speed & 0.221 & 0.040 & 34 \\
Hand Grip Strength & 0.170 & 0.045 & 34 \\
\hline
\end{tabular}


Pearson correlation test, the $\mathrm{p}$ value is significant if $\mathrm{p}<0.05$, the strength of the correlation is very weak if $\mathrm{r}<0.2$, weak if $r=0.2-0.4$, moderate if 0.4-0.6, strong if $0,6-0.8$ and very strong if $>0.8$

Table 4. Multivariate Analysis of Vitamin D Linear Regression in the elderly

\begin{tabular}{lccc}
\hline & $\mathrm{R}$ & $\mathrm{p}$ & $\mathrm{N}$ \\
\hline Age & -.192 & .092 & 34 \\
Muscle mass & .230 & .005 & 34
\end{tabular}

Pearson correlation test, the $\mathrm{p}$ value is significant if $\mathrm{p}<0.05$, the strength of the correlation is very weak if $\mathrm{r}<0.2$, weak if $r=0.2-0.4$, moderate if $r=0.4-0.6$, strong if $r=0.6-0.8$ and very strong if $r>0.8$

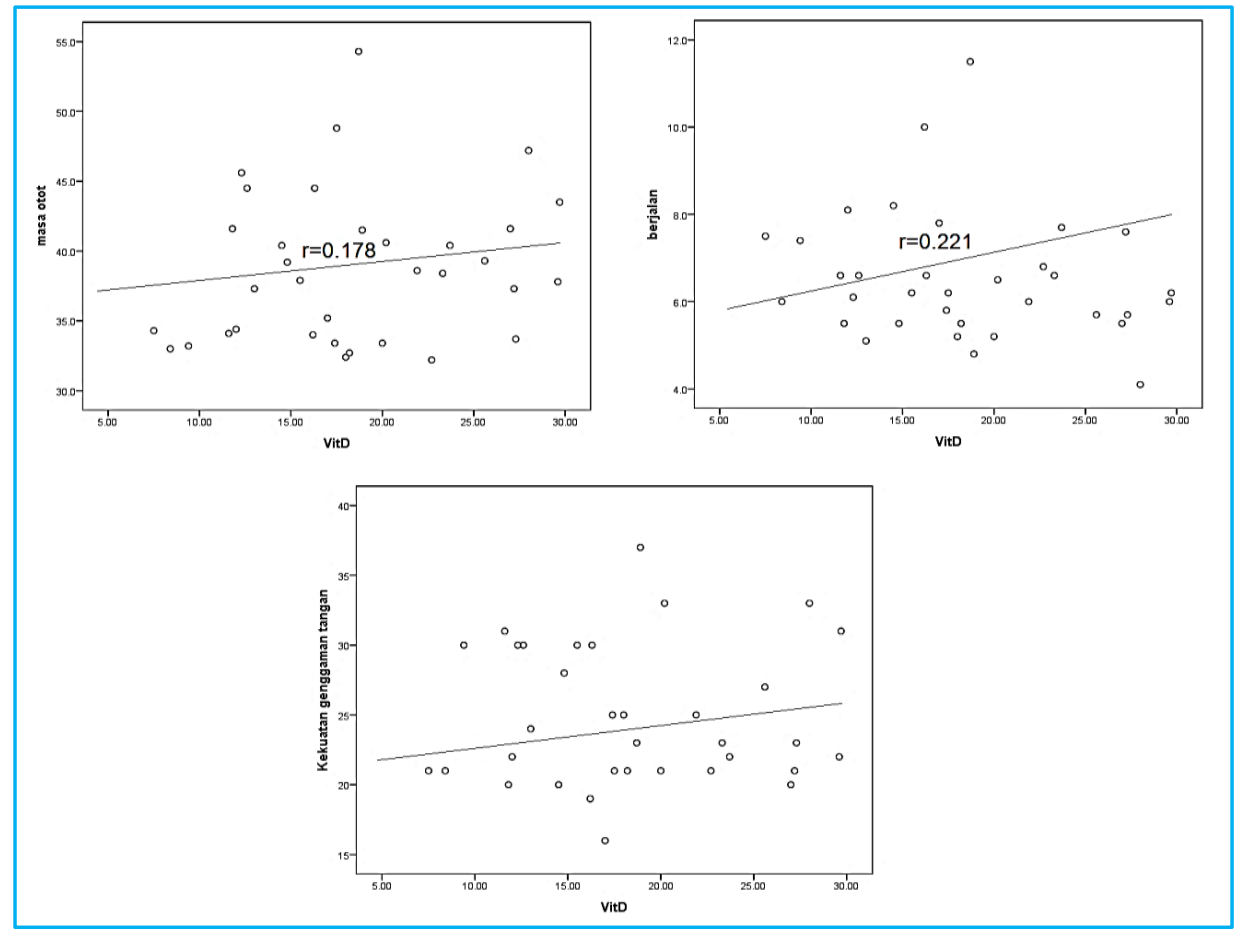

Figure 1. Graph of Vitamin D Correlation with Muscle Mass, Walking Speed and Hand Grip Strength

\section{Discussion}

This study was dominated by 21 (61.8\%) samples with vitamin D deficiency (vitamin D levels $<20 \mathrm{ng} / \mathrm{mL}$ ) and $13(38.2 \%)$ samples experiencing insufficiency (vitamin D levels $20-30 \mathrm{ng} / \mathrm{mL}$ ) with a mean of $18.4 \pm$ $6.29 \mathrm{ng} / \mathrm{mL}$. This study is in line with the research of Conzade et al. 2019 which found differences in muscle mass and muscle strength in the elderly who have serum vitamin $\mathrm{D}$ levels $\leq 25 \mathrm{nmol} / \mathrm{nL}$ with elderly people who have serum vitamin D levels of $26-50$ $\mathrm{nmol} / \mathrm{nL}$. The reduced serum vitamin $\mathrm{D}$ levels in the body, the higher the incidence of sarcopenia in the elderly. ${ }^{10}$

Research conducted by Mendes et al who conducted a similar study on 834 samples who were over 60 years old and dominated by elderly people who experienced a vitamin $\mathrm{D}$ deficiency of $45 \%$ while $27 \%$ of the sample had insufficiency and others had normal vitamin D levels. 89 Oba et al al in 2020 found that at 257 elderly people, the average vitamin $\mathrm{D}$ in the body was 18 $\mathrm{ng} / \mathrm{mL}$ with the lowest level was $15 \mathrm{ng} / \mathrm{mL}$ and the highest was $21 \mathrm{ng} / \mathrm{mL} .90$

Vitamin D deficiency and insufficiency is common in various regions around the world. Vitamin D 
insufficiency was defined as a serum 25hydroxyvitamin D $(25[\mathrm{OH}] \mathrm{D})$ level $<20 \mathrm{ng} / \mathrm{mL}$ by the Institute of Medicine. ${ }^{21}$ Newborns and the elderly are the age group with the greatest risk for vitamin D deficiency ${ }^{23}$. In addition, vitamin D levels were linked to gender. The central role of vitamin $\mathrm{D}$ in calcium homeostasis is well known and is related to seasonality, sun exposure, body mass index, physical activity, smoking and alcohol consumption. ${ }^{26-30}$ Vitamin D and calcium are known to be important for the skeletal system, and low vitamin D levels lead to less intestinal calcium absorption, and higher PTH levels. In addition to increasing tubular reabsorption of calcium and production of active vitamin D in the kidneys, PTH activates osteoblasts to increase the number of osteoclasts that dissolve bone matrix. This leads to faster bone turnover and thus osteopenia and osteoporosis. 50

Specific receptors for 1.25-dihydroxyvitamin D (VDR) are present in the bones and gastrointestinal tract, where calcium flow is most active.24-26 In addition, vitamin $\mathrm{D}$ receptors are also present in skeletal muscle, 20,23,24 but physiological functions are and its relevance to normal muscle physiology is not well understood. It is estimated that VDR in muscle tissue is an intranuclear receptor that can bind 1.25dihydroxyvitamin D (calcitriol) with high affinity to further act as a transcription factor for protein synthesis. 26,28,29 Vitamin D deficiency has traditionally been associated with disorders of the bones such as rickets, osteomalacia, and osteoporosis. Various studies have found another role for vitamin D and the effects of its deficiency on various organ systems ${ }^{36}$

There are a number of direct and indirect effects of aging on vitamin Dlevels.23-26 Aging reduces the production of 1.25-dihydroxyvitamin D (1.25 [OH] $2 \mathrm{D})$, which is the active form of vitamin D, by up to $50 \% .23$ This results from decreased kidney function in the elderly. Renal function decreases with age, decreases in the renal enzyme 1a-hydroxylase which converts 25 $(\mathrm{OH})$ D into its active form, $1.25(\mathrm{OH}) 2$ D.The serum level of $1.25(\mathrm{OH}) 2 \mathrm{D}$ is inversely proportional to the level of serum creatinine and glomerular filtration rate
(GFR). It was further found that a deficiency of 1.25 $(\mathrm{OH}) 2$ vitamin $\mathrm{D}$ triggers a decrease in the formation of $1.25(\mathrm{OH}) 2$ vitamin $\mathrm{D}$, because the conversion to the active form of vitamin $\mathrm{D}$ in the kidneys is dependent on adequate supplies of vitamin D25 substrate. ${ }^{25}$ The lower production of pro-vitamin $\mathrm{D}$ in the skin in the elderly also affects vitamin D23 levels. ${ }^{23}$ The decrease in the formation of pro-vitamin D produced in the skin of the elderly is associated with less reaction to UV rays and a reduced ability to produce 7-dehydrocholesterol in the skin. ${ }^{23,28}$

In this study, there was a significant correlation between muscle mass and grip strength with vitamin $\mathrm{D}$ with weak correlation strength and walking speed with vitamin $\mathrm{D}$ with moderate correlation strength. The multivariate test results showed that the increasing age, the lower the vitamin D levels in the body and the lower the vitamin D levels, the smaller the muscle mass.

Consistent with this study, Mendes et al. Found a strong positive correlation between vitamin $\mathrm{D}$ and muscle mass, walking speed and hand grip strength. 89 Oba et al also found a correlation between vitamin D (25 OHD) muscle mass, hand grip strength, walking speed, and lower limb function. ${ }^{90}$ Skaaby et al in 2018 concluded that low vitamin D levels have been linked to muscle mass, body performance and a number of diseases commonly found among the elderly, for example, osteoporosis, falls and fractures and sarcopenia. 24

Vitamin D deficiency is known to cause muscle weakness $^{2}$, and muscles may need vitamin $\mathrm{D}$ for optimal functioning because muscles have $\mathrm{VDR}^{2}$. Thus, muscle strength is shown to increase when vitamin D levels increase from 4 to $>40 \mathrm{ng} / \mathrm{mL}$ (10-100 nmol/L). 52 Several studies have suggested a possible effect of vitamin $\mathrm{D}$ on the development of sarcopenia. ${ }^{13,52}$ In line with previous studies, a study of 864 men and women by Walsh et al. ${ }^{13}$ found that genetic variation in VDR was moderately associated with muscle strength in both sexes and the risk of sarcopenia in women. Vitamin D supplements have the potential to reduce the risk of sarcopenia and prevent disability. In a 
randomized controlled trial (RCT) of 380 adults with sarcopenia, vitamin $\mathrm{D}$, and leucine-fortified whey protein were given as a supplement for 13 weeks and this resulted in increased muscle mass and lower limb function. 48

About one-third of women aged between 60 and 70 years and two-thirds of women 80 years or older have osteoporosis. ${ }^{50}$ It is estimated that nearly half of women will experience an osteoporotic fracture in the rest of their lives. Risk factors for osteoporosis include, for example, age, female sex, menopause, inactivity, and inadequate intake of calcium and vitamin D. 51 Vitamin $\mathrm{D}$ and calcium are known to be important for the skeletal system, and low levels of vitamin D lead to less intestinal calcium absorption, and higher levels of PTH. In addition to increasing tubular reabsorption of calcium and production of renal active vitamin D, PTH activates osteoblasts to increase the number of osteoclasts that dissolve bone matrix. This leads to faster bone turnover and thus osteopenia and osteoporosis. 51

A meta-analysis of observational studies found that farmers working in the fall had lower levels of vitamin $\mathrm{D}(<20 \mathrm{ng} / \mathrm{mL})$ than non-fall ${ }^{34}$. In many RCT studies it was found that only doses of vitamin $\mathrm{D}$ that were sufficiently large were efficient in preventing falls, one RCT study even reported an increased risk of falls in elderly women, after giving each year a dose of 500.000 IU of vitamin D supplementation for 3-5 years a reduced risk of falls compared to the placebo group ${ }^{35} \mathrm{~A}$ review study found that supplementation vitamin $\mathrm{D}$ of $\geq 800$ IUs reduces the risk of falls in the elderly. ${ }^{36} \mathrm{~A}$ meta-analysis showed that 800 IU of vitamin D3 per day plus calcium was more effective in preventing and lowering the risk of falls in the elderly 400 IU of vitamin D3 per day. ${ }^{7}$

RCTs primarily examine the effects of vitamin D on hip and nonvertebral fractures. A meta-analysis of 20 large RCTs showed that fractures were reduced in people who consumed $>400$ IU of vitamin D supplementation per day. ${ }^{39}$ An analysis of 11 RCTs found that doses $>800$ IUs / day of vitamin D have a beneficial effect in preventing hip and nonvertebral fractures in the elderly. ${ }^{6,38}$ Serum levels of Vitamin D absorption appear to be important for example, the Women's Health Initiative study reported that levels of vitamin $\mathrm{D}$ serum vitamin $\mathrm{D} \leq 26 \mathrm{ng} / \mathrm{mL}$ had little effect on fracture risk 48.39

\section{Conclusion}

There is a significant correlation between muscle mass and grip strength with vitamin $\mathrm{D}$ with weak correlation strength and walking speed with vitamin $\mathrm{D}$ with moderate correlation strength. The multivariate test results showed that the increasing age, the lower the vitamin $\mathrm{D}$ levels in the body and the lower the vitamin $\mathrm{D}$ levels, the smaller the muscle mass.

\section{References}

1. Boy, Elman. Prevalensi Malnutrisi Pada Usia lanjut dengan Pengukuran Mini Nutritional Assessment (MNA) di Pusekesmas. HerbMedicine Journal, 2019, 2.1.

2. Setiati, Siti. Geriatric Medicine, Sarkopenia, Frailty, dan Kualitas Hidup Pasien Usia Lanjut: Tantangan Masa Depan Pendidikan, Penelitian dan Pelayanan Kedokteran di Indonesia. eJournal Kedokteran Indonesia, 2014.

3. Setiati S, Seto E, Sumantri S. Frailty profile of elderly outpatient in Cipto Mangunkusumo Hospital Jakarta. In press. 2013

4. Sudarma V, Halim L. High skeletal muscle mass is associated with increased serum 25 $(\mathrm{OH})$ D levels in elderly. Universa Medicina, $2017 ; 36(3): 236-42$.

5. Caniago, Muhammad Rizky, Dwi Ngestiningsih, and Faizah Fulyani. Hubungan Antara Kadar Vitamin D dengan Kekuatan Genggaman Tangan Usia lanjut. Diponogoro Medical Journal, 2019.

6. Yazar, Tamer; Yazar, Hülya Olgun. Prevalance of sarkopenia according to decade. Clinical nutrition ESPEN, 2019, 29: 137-141. 
7. Scimeca, Manuel, et al. "Vitamin D receptor in muscle atrophy of elderly patients: a key element of osteoporosis-sarkopenia connection." Aging and disease 9.6, 2018: 952.

8. Holick MF: Vitamin D deficiency. N Engl J Med 2007;357:266-281.

9. Cruz-Jentoft, Alfonso J., et al. "Sarkopenia: revised European consensus on definition and diagnosis." Age and ageing 48.1 (2018): 16-31.

10. Conzade, Romy, et al. "Vitamin D in Relation to Incident Sarkopenia and Changes in Muscle Parameters Among Older Adults: The KORAAge Study." Calcified tissue international,2019, $1-10$.

11. Liberman, Keliane, et al. "Thirteen weeks of supplementation of vitamin D and leucineenriched whey protein nutritional supplement attenuates chronic low-grade inflammation in sarcopenic older adults: the PROVIDE study." Aging clinical and experimental research,2019, 1-10.

12. Bischoff HA, Stahelin HB, Urscheler N, Ehrsam R, Vonthein R, Perrig-Chiello P, Tyndall A, Theiler R 1999 Muscle strength in the elderly: Its relation to vitamin D metabolites. Arch Phys Med Rehabil, 1999, 80:54 -58.

13. Garcia, Matheus, et al. "Vitamin D, muscle recovery, sarkopenia, cachexia, and muscle atrophy." Nutrition 60 (2019): 66-69.

14. El Hajj, Cynthia, et al. "Vitamin D supplementation and muscle strength in presarcopenic elderly Lebanese people: a randomized controlled trial." Archives of osteoporosis, 2019, 14.1: 4.

15. Stein MSWJ, Scherer SC, Walton SL, Chick P, DiCarlantonio M, Zajac JD, Flicker L, Epid GD, Falls relate to vitamin $\mathrm{D}$ and parathyroid hormone in an Australian nursing home and hostel. J Am Geriatr Soc, 1999, 47:1195-1201.

16. Chapuy MC, Arlot ME, Duboeuf F, Brun J, Crouzet B, Arnaud S, Delmas PD, Meunier PJ, Vitamin D3 and calcium to prevent hip fractures in the elderly women. N Engl J Med, 1992, 327:1637-1642.

17. Dawson-Hughes B, Harris SS, Krall EA, Dallal GE, Effect of calcium and vitamin D supplementation on bone density in men and women 65 years of age or older. N Engl J Med, 1997, 337:670 - 676.

18. Pfeifer M, Begerow B, Minne HW, Abrams C, Nachtigall D, Hansen C, Effects of a short-term vitamin $\mathrm{D}$ and calcium supplementation on body sway and secondary hyperparathyroidism in elderly women. J Bone Miner Res, 2000, 15:1113-1118.

19. Glerup H, Mikkelsen K, Poulsen L, Hass E, Overbeck S, Andersen H, Charles P, Eriksen EF,Hypovitaminosis D myopathy without biochemical signs of osteomalacic bone involvement. Calcif Tissue Int, 2000, 66:419 424.

20. Fedarko, Neal S. "Theories and mechanisms of aging." Geriatric Anesthesiology. Springer, Cham, 2018. 19-25.

21. Blundell, Adrian, and Tahir Masud. "Teaching and learning the content of geriatric medicine." Learning Geriatric Medicine. Springer, Cham, 2018. 7-15.

22. Naseeb, M. A., \& Volpe, S. L. Protein and exercise in the prevention of sarkopenia and aging. Nutrition research, 2017, 40, 1-20

23. Boirie, Yves, and Christelle Guillet. "Fast digestive proteins and sarkopenia of aging." Current Opinion in Clinical Nutrition \& Metabolic Care 21.1 (2018): 37-41.

24. Skaaby, Tea, Betina H. Thuesen, and Allan Linneberg. "Vitamin D, Sarkopenia and Aging." Vitamin D in Clinical Medicine. Vol. 50. Karger Publishers, 2018. 177-188.

25. Calvani, Riccardo, et al. "Biomarkers for physical frailty and sarkopenia: state of the science and future developments." Journal of cachexia, sarkopenia and muscle 6.4 (2015) : 278-286. 
26. Bianchi, Lara, et al. "Prevalence and clinical correlates of sarkopenia, identified according to the EWGSOP definition and diagnostic algorithm, in hospitalized older people: The GLISTEN Study." Journals of Gerontology Series A: Biomedical Sciences and Medical Sciences 72.11 (2017): 1575-1581.

27. Cruz-Jentoft, Alfonso J., et al. "Sarkopenia: European consensus on definition and diagnosisReport of the European Working Group on Sarkopenia in Older PeopleA. J. Cruz-Gentoft et al." Age and ageing 39.4, 2010: 412-423.

28. Bian, Ai-Lin, et al. A study on relationship between elderly sarkopenia and inflammatory factors IL-6 and TNF-a. European journal of medical research, 2017, 22.1: 25.

29. McKee, Alexis, and John E. Morley. "Hormones and Sarkopenia." Current Opinion in Endocrine and Metabolic Research, 2019.

30. Bruce, Bonnie, and James F. Fries. "The health assessment questionnaire (HAQ)." Clinical and experimental rheumatology 23.5, 2005: S14.

31. Phaniendra, Alugoju; Jestadi, Dinesh Babu; Periyasamy, Latha. Free radicals: properties, sources, targets, and their implication in various diseases. Indian journal of clinical biochemistry, 2015, 30.1: 11-26.

32. Patel HP, Syddall HE, Jameson K, Robinson S, Denison H, Roberts HC, et al: Prevalence of sarkopenia in community-dwelling older people in the UK using the European Working Group on Sarkopenia in Older People (EWGSOP) definition: findings from the Hertfordshire Cohort Study (HCS). Age Ageing 2013;42:378-384.

33. Brown JC, Harhay MO, Harhay MN: Sarkopenia and mortality among a populationbased sample of community-dwelling older adults. J Cachexia Sarkopenia Muscle 2016;7:290-298.
34. Ryall JG, Schertzer JD, Lynch GS: Cellular and molecular mechanisms underlying age-related skeletal muscle wasting and weakness. Biogerontology 2008; 9:213-228.

35. Brioche T, Pagano AF, Py G, Chopard A: Muscle wasting and aging: experimental models, fatty infiltrations, and prevention. Mol Aspects Med 2016;50: 56-87.

36. Bauer JM, Verlaan S, Bautmans I, Brandt K, Donini LM, Maggio M, et al: Effects of a vitamin $\mathrm{D}$ and leucine-enriched whey protein nutritional supplement on measures of sarkopenia in older adults, the PROVIDE study: a randomized, double-blind, placebocontrolled trial. J Am Med Dir Assoc 2015;16:740- 747 .

37. Walsh S, Ludlow AT, Metter EJ, Ferrucci L, Roth SM: Replication study of the vitamin D receptor (VDR) genotype association with skeletal muscle traits and sarkopenia. Aging Clin Exp Res 2016;28:435-442.

38. Boonen S, Bischoff-Ferrari HA, Cooper C, Lips $\mathrm{P}$, Ljunggren $\mathrm{O}$, Meunier PJ, et al: Addressing the musculoskeletal components of fracture risk with calcium and vitamin D: a review of the evidence. Calcif Tissue Int 2006;78:257-270

39. Meehan M, Penckofer S: The role of vitamin D in the aging adult. J Aging Gerontol 2014;2:6071.

40. Annweiler C, Beauchet O: Questioning vitamin D status of elderly fallers and nonfallers: a meta-analysis to address a "forgotten step." J Intern Med 2015; 277:16-44.

41. Sanders KM, Stuart AL, Williamson EJ, Simpson JA, Kotowicz MA, Young D, et al: Annual high-dose oral vitamin $\mathrm{D}$ and falls and fractures in older women: a randomized controlled trial. JAMA 2010;303:1815- 1822.

42. Annweiler C, Montero-Odasso M, Schott AM, Berrut G, Fantino B, Beauchet O: Fall prevention and vitamin $\mathrm{D}$ in the elderly: an 
overview of the key role of the non-bone effects. J Neuroeng Rehabil 2010;7: 50.

43. Bischoff-Ferrari HA, Willett WC, Wong JB, Stuck AE, Staehelin HB, Orav EJ, et al: Prevention of nonvertebral fractures with oral vitamin D and dose dependency: a metaanalysis of randomized controlled trials. Arch Intern Med 2009;169:551-561.

44. Bischoff-Ferrari HA, Willett WC, Orav EJ, Lips P, Meunier PJ, Lyons RA, et al: A pooled analysis of vitamin $\mathrm{D}$ dose requirements for fracture prevention. N Engl J Med 2012;367:40-49.

45. Jackson RD, LaCroix AZ, Gass M, Wallace RB, Robbins J, Lewis CE, et al: Calcium plus vitamin $\mathrm{D}$ supplementation and the risk of fractures. N Engl J Med 2006;354:669-683.

46. Avenell A, Gillespie WJ, Gillespie LD, O'Connell D: Vitamin D and vitamin D analogues for preventing fractures associated with involutional and postmenopausal osteoporosis. Cochrane Database Syst Rev 2009;2:CD000227.

47. Gonzalez, Maria Cristina, and Steven B. Heymsfield. "Bioelectrical impedance analysis for diagnosing sarkopenia and cachexia: what are we really estimating?." Journal of cachexia, sarkopenia and muscle 8.2 (2017): 187-189.

48. Chapuy MC, Arlot ME, Duboeuf F, Brun J, Crouzet B, Arnaud S, et al: Vitamin D3 and calcium to prevent hip fractures in elderly women. N Engl J Med 1992;327:1637-1642.

49. Manoy, Pacharee, et al. "Elevated serum leptin levels are associated with low vitamin D, sarcopenic obesity, poor muscle strength, and physical performance in knee osteoarthritis." Biomarkers 22.8 (2017): 723730 .

50. David Scoot, leigh B, James Fell, at al. A prospective study of the association between 25-hydroxy-vitamin D, sarcopenia progression and physical activity in older adult, Clinical Endocrinology, 2010.

51. Seo, Ji A., et al. "Association between visceral obesity and sarkopenia and vitamin D deficiency in older Koreans: the Ansan Geriatric Study." Journal of the American Geriatrics Society 60.4 (2012): 700-706.

52. Mizhgan Fatima, Sharon L. Brennan-Olsen, and Gustavo Duque. Therapeutic approaches to osteosarkopenia: insights for the clinician. Ther Adv Musculoskelet Dis. 2019; Published $\begin{array}{llll}\text { online } & 2019 & \text { Aug }\end{array}$ doi: $10.1177 / 1759720 X 19867009$

53. Hirschfeld HP ${ }^{1}, \underline{\text { Kinsella } \mathrm{R}^{2}}$, Duque $\mathrm{G}^{3,4}$. Osteosarkopenia: where bone, muscle, and fat collide. Osteoporos Int. 2017 Oct;28(10):2781-2790. doi: 10.1007/s00198017-4151-8. Epub 2017 Jul 22.

54. Alfonso J Cruz-Jentoft, ${ }^{1}$ Gülistan Bahat, ${ }^{2}$ Jürgen Bauer, ${ }^{3}$ Yves Boirie, ${ }^{4}$ Olivier Bruyère, ${ }^{5}$ $\underline{\text { Tommy Cederholm }},{ }^{6}$ Cyrus Cooper, ${ }^{7}$ Francesco Landi, ${ }^{8}$ Yves Rolland, 9 Avan Aihie Sayer, ${ }^{10}$ Stéphane M Schneider, ${ }^{11}$ Cornel C Sieber, ${ }^{12}$ Eva Topinkova, ${ }^{13}$ Maurits Vandewoude, ${ }^{14}$ Marjolein Visser, ${ }^{15}$ Mauro Zamboni, Sarkopenia: revised European consensus on definition and diagnosis. Age Ageing. 2019 Jan; 48(1): 16-31. Published online 2018 Sep 24. doi: 10.1093/ageing/afy169

55. Sorensen OH, Lund B, Saltin B, Andersen RB, Hijorth L, Melsen F, Mosekilde L Myopathy in bone loss of ageing: Improvement by treatment with 1 alpha-hydroxycholecalciferol and calcium. Clin Sci (Lond), 1997, 56:157-161.

56. Owens, D. J. et al. A systems-based investigation into vitamin $\mathrm{D}$ and skeletal muscle repair, regeneration, and hypertrophy. American Journal of Physiology Endocrinology And Metabolism, v. 309, n. 12, p. E1019-E1031, 2015.

57. Olsson, K. et al. Evidence for Vitamin D Receptor Expression and Direct Effects of 
1a,25(OH) 2 D 3 in Human Skeletal Muscle Precursor Cells. Endocrinology, v. 157, n. 1, p. 98-111, 2016.

58. Haussler, M. R.; Norman, A. W. Chromosomal Receptor for a Vitamin D Metabolite. Proceedings of the National Academy of Sciences, v. 62, n. 1, p. 155-162, 1969.

59. Santillan, G. et al. Evidence that TRPC3 is a molecular component of the $1 \mathrm{a}, 25(\mathrm{OH}) 2 \mathrm{D} 3-$ activated capacitative calcium entry (CCE) in muscle and osteoblast cells. Journal of Steroid Biochemistry and Molecular Biology, v. 89-90, p. 291-295, 2004a.

60. Santillan, G. et al. TRPC3-like protein and Vitamin D receptor mediate 1a,25(OH)2D3induced SOC influx in muscle cells. International Journal of Biochemistry and Cell Biology, v. 36, n. 10, p. 1920-1928, 2004b.

61. Takeuchi, Izumi, et al. "Effects of branchedchain amino acids and vitamin D supplementation on physical function, muscle mass and strength, and nutritional status in sarcopenic older adults undergoing hospitalbased rehabilitation: A multicenter randomized controlled trial." Geriatrics \& Gerontology International,2019,19.1: 12-17.

62. Franceschi, C.; Campisi, J. Chronic inflammation (inflammaging) and its potential contribution to age-associated diseases. J. Gerontol. A Biol. Sci. Med. Sci. 2014, 69, S4S9. [CrossRef] [PubMed] 3

63. Frasca, D.; Blomberg, B.B. Inflammaging decreases adaptive and innate immune responses in mice and humans. Biogerontology 2016, 17, 7-19. [CrossRef] [PubMed]

64. Sansoni, P.; Vescovini, R.; Fagnoni, F.; Biasini, C.; Zanni, F.; Zanlari, L.; Telera, A.; Lucchini, G.; Passeri, G.; Monti, D.; et al. The immune system in extreme longevity. Exp. Gerontol. 2008, 43, 61-65. [CrossRef] [PubMed]

65. Maggio, M.; Guralnik, J.M.; Longo, D.L.; Ferrucci, L. Interleukin-6 in aging and chronic disease: A magnificent pathway. J. Gerontol. A Biol. Sci. Med. Sci. 2006, 6, 575-584. [CrossRef]

66. Giuliani, N.; Sansoni, P.; Girasole, G.; Vescovini, R.; Passeri, G.; Passeri, M.; Pedrazzoni, M. Serum interleukin-6, soluble interleukin-6 receptor and soluble gp130 exhibit different patterns of age- and menopause-related changes. Exp. Gerontol. 2001, 36, 547-557. [CrossRef]

67. Stenholm, S.; Maggio, M.; Lauretani, F.; Bandinelli, S.; Ceda, G.P.; Di Iorio, A.; Giallauria, F.; Guralnik, J.M.; Ferrucci, L. Anabolic and catabolic biomarkers as predictors of muscle strength decline: The InCHIANTI study. Rejuvenation Res. 2010, 13, 3-11. [CrossRef] [PubMed]

68. Baylis, D.; Ntani, G.; Edwards, M.H.; Syddall, H.E.; Bartlett, D.B.; Dennison, E.M.; MartinRuiz, C.; von Zglinicki, T.; Kuh, D.; Lord, J.M.; et al. Inflammation, telomere length, and grip strength: A 10-year longitudinal study. Calcif. Tissue Int. 2014, 95, 54-63. [CrossRef] [PubMed]

69. Leng, S.X.; Xue, Q.L.; Tian, J.; Walston, J.D.; Fried, L.P. Inflammation and frailty in older women. J. Am. Geriatr. Soc. 2007, 55, 864871. [CrossRef] [PubMed

70. Giunta, B.; Fernandez, F.; Nikolic, W.; Obregon, D.; Rrapo, E.; Town, T.; Tan, J. Inflammaging as a prodrome to Alzheimer's disease. J. Neuroinflammation 2008, 5. [CrossRef] [PubMed]

71. Stepanova, M.; Rodriguez, E.; Birerdinc, A.; Baranova, A. Age-independent rise of inflammatory scores may contribute to accelerated aging in multimorbidity. Oncotarget 2015, 6, 1414-1421. [CrossRef] [PubMed]

72. Ostan, R.; Lanzarini, C.; Pini, E.; Scurti, M.; Vianello, D.; Bertarelli, C.; Fabbri, C.; Izzi, M.; Palmas, G.; Biondi, F.; et al. Inflammaging and 
cancer: A challenge for the Mediterranean diet.

Nutrients 2015, 7, 2589-2621. [CrossRef] [PubMed]

73. Brown, P.J.; Roose, S.P.; Zhang, J.; Wall, M.; Rutherford, B.R.; Ayonayon, H.N.; Butters, M.A.; Harris, T.; Newman, A.B.; Satterfield, S.; et al. Inflammation, depression, and slow gait: A high mortality phenotype in later life. J. Gerontol. A Biol. Sci. Med. Sci. 2016, 71, 221227. [CrossRef] [PubMed]

74. Giovannini, S.; Onder, G.; Liperoti, R.; Russo, A.; Carter, C.; Capoluongo, E.; Pahor, M.; Bernabei, R.; Landi, F. Interleukin-6, Creactive protein, and tumor necrosis factoralpha as predictors of mortality in frail, community-living elderly individuals. J. Am. Geriatr. Soc. 2011, 59, 1679-1685. [CrossRef] [PubMed]

75. Cederholm, T.; Nouvenne, A.; Ticinesi, A.; Maggio, M.; Lauretani, F.; Ceda, G.P.; Borghi, L.; Meschi, T. The role of malnutrition in older persons with mobility limitations. Curr. Pharm. Des. 2014, 20, 3173-3177. [CrossRef] [PubMed]

76. Jensen, G.L. Malnutrition and inflammation"Burning down the house": Inflammation as an adaptive physiologic response versus selfdestruction? J. Parenter. Enteral Nutr. 2015, 39, 56-62. [CrossRef] [PubMed] 18. Batt, J.; Dos Santos, C.C.; Herridge, M.S. Muscle injury during critical illness. J. Am. Med. Assoc. 2013, 310, 1569-1570. [CrossRef] [PubMed]

77. Nouvenne, A.; Ticinesi, A.; Lauretani, F.; Maggio, M.; Lippi, G.; Prati, B.; Borghi, L.; Meschi, T. The prognostic value of highsensitivity C-reactive protein and prealbumin for short-term mortality in acutely hospitalized multimorbid elderly patients: A prospective cohort study. J. Nutr. Health Aging 2016, 20, 462-468. [CrossRef] [PubMed]

78. Haran, P.H.; Rivas, D.A.; Fielding, R.A. Role and potential mechanisms of anabolic resistance in sarkopenia. J. Cachexia Sarkopenia Muscle 2012, 3, 157-162. [CrossRef] [PubMed]

79. Buffière, C.; Mariotti, F.; Savary-Auzeloux, I.; Migné, C.; Meunier, N.; Hercberg, S.; Cano, N.; Rémond, D.; Duclos, M.; Dardevet, D. Slight chronic elevation of C-reactive protein is associated with lower aerobic fitness but does not impair meal-induced stimulation of muscle protein metabolism in healthy old men. J. Physiol. 2015, 593, 1259-1272. [CrossRef] [PubMed]

80. Moore, D.R.; Churchward-Venne, T.A.; Witard, O.; Breen, L.; Burd, N.A.; Tipton, K.D.; Phillips, S.M. Protein ingestion to stimulate myofibrillar protein synthesis requires greater relative protein intakes in healthy older versus younger men. J. Gerontol. A Biol. Sci. Med. Sci. 2015, 70, 57-62. [CrossRef] [PubMed]

81. Markofski, M.M.; Dickinson, J.M.; Drummond, M.J.; Fry, C.S.; Fujita, S.; Gundermann, D.M.; Glynn, E.L.; Jennings, K.; Paddon-Jones, D.; Reidy, P.T.; et al. Effect of age on basal muscle protein synthesis and mTORC1 signaling in a large cohort of young and older men and women. Exp. Gerontol. 2015, 65, 1-7. [CrossRef] [PubMed]

82. Laviano, A.; Koverech, A.; Mari, A. Cachexia: Clinical features when inflammation drives malnutrition. Proc. Nutr. Soc. 2015, 74, 348354. [CrossRef] [PubMed] Breen, L.; Stokes, K.A.; Churchward-Venne, T.A.; Moore, D.R.; Baker, S.K.; Smith, K.; Atherton, P.J.; Phillips, S.M. Two weeks of reduced activity decreases leg lean mass and induces "anabolic resistance" of myofibrillar protein synthesis in healthy elderly. J. Clin. Endocrinol. Metab. 2013, 98, 2604-2612. [CrossRef] [PubMed]

83. Hickson, M. Nutritional interventions in sarkopenia: A critical review. Proc. Nutr. Soc. 2015, 74, 378-386. [CrossRef] [PubMed] 
84. Maggio, M.; De Vita, F.; Lauretani, F.; Buttò, V.; Bondi, G.; Cattabiani, C.; Nouvenne, A.; Meschi, T.; Dall'Aglio, E.; Ceda, G.P. IGF-1, the cross road of the nutritional, inflammatory and hormonal pathways to frailty. Nutrients 2013, 5, 4184-4205. [CrossRef] [PubMed]

85. Maggio, M.; Ble, A.; Ceda, G.P.; Metter, E.J. Decline in insulin-like growth factor-I levels across adult life span in two large population studies. J. Gerontol. A Biol. Sci. Med. Sci. 2006, 61, 182-183. [CrossRef] [PubMed]

86. Cappola, A.R.; Xue, Q.L.; Ferrucci, L.; Guralnik, J.M.; Volpato, S.; Fried, L.P. Insulinlike growth factor I and interleukin-6 contribute synergistically to disability and mortality in older women. J. Clin. Endocrinol. Metab. 2003, 88, 2019-2025. [CrossRef] [PubMed]

87. Maggio, M.; Artoni, A.; Lauretani, F.; Borghi, L.; Nouvenne, A.; Valenti, G.; Ceda, G.P. The impact of omega-3 fatty acids on osteoporosis. Curr. Pharm. Des. 2009, 15, 4157-4164. [CrossRef] [PubMed]

88. Ticinesi, Andrea, et al. Nutrition and inflammation in older individuals: focus on vitamin $\mathrm{D}, \mathrm{n}-3$ polyunsaturated fatty acids and whey proteins. Nutrients, 2016, 8.4: 186.

89. Mendes, J., et al. Vitamin D status and functional parameters: A cross-sectional study in an older population. PLoS One, 2018, 13.8: e0201840.

90. Oba, Kazuhito, et al. Serum growth differentiation factor 15 level is associated with muscle strength and lower extremity function in older patients with cardiometabolic disease. Geriatrics \& Gerontology International, 2020, 20.10: 980-987.

91. Ashton-Miller JA, Alexander NB. Biomechanics of Mobility. Hazzard's Geriatric Medicine and Gerontology. 7th edition, Chapter 114, 2017; p. 1739-53
92. Manini TM, Gundermann DM, Clarck BC. Aging of The Muscles and Joints. Hazzard's Geriatric Medicine and Gerontology. 7th edition, Chapter 113, 2017; p.1715-37 